\title{
The Model of Generating Affective Commitment In Mining Companies based Information Technology
}

\author{
Esti Liana $^{1}$, Abdullah Ade Suryobuwono ${ }^{2}$. Muhammad DWI Satriyanto ${ }^{3}$, Afi Parnawi ${ }^{4}$, \\ Munir Azhari ${ }^{5}$, Rubadi ${ }^{6}$, Prasadja Ricardianto ${ }^{7}$, Nurwulan Kusuma Devi ${ }^{8}$ \\ 1estimrshartono@gmail.com, ${ }^{2}$ adesuryo.lptl@itltrisakti.ac.id, ${ }^{3}$ dwi.satriyanto@gmail.com, ${ }^{4}$ afiparnawi@uis.ac.id, \\ ${ }^{5}$ munir.azhari@gmail.com, ${ }^{6}$ rubadi.supatma@gmail.com, ${ }^{7}$ ricardianto@gmail.com, ${ }^{8}$ nurwulankusumadevi026@gmail.com
}

Article History: Received: 11 January 2021; Accepted: 27 February 2021; Published online: 5 April 2021

\begin{abstract}
This research was conducted at a coal mining company in Tanjung Enim, South Sumatra. This aim is to analyze the influence of organizational culture and transformational leadership style on job satisfaction to generate affective commitment based information technology. This method uses quantitative methods with a population of 140 employees and a sample of 111 and with data research techniques in the form of questionnaires and library data. Methods of data analysis using multiple regression analysis, validity test, reliability test, coefficient of determination, partial test with t-test. The results showed that organizational culture has a positive effect on job satisfaction with a significant value of $0.000<0.05$ and a $\beta$ value of 0.457 . Transformational leadership style has a positive effect on job satisfaction with a sig value of $0.000<0.05$ and a $\beta$ value of 0.363 .
\end{abstract}

Keywords: Organizational Culture, Transformational Leader Style, Job Satisfaction, Affective Commitment, Information Technology

\section{Introduction}

Human resources have a very important role in every activity of the organization, without the existence of human resources organizational activities will not run well. Culture in an organization can provide coercion and encouragement for employees to act and behave by what the organization expects so that the applicable organizational culture will not only produce quality employees but will also provide assurance to all employees to develop with the organization. Developing an organizational culture means developing human resources and maintaining an organizational culture means empowering human resources.

A leader has a leadership style that is different from one another, a leadership style is better or worse than each leadership style. Especially in the industrial era 4.0, the development is increasingly fast accompanied by the growth of various companies, so that competition between companies cannot be avoided. By maximizing the development of company resources, the Company is required to be able to face challenges that come from outside and from within the company. Transformational leadership has a personality where a person who has a transformational leadership style can inspire followers to change expectations, perceptions, and motivation to work towards common goals based information technology.

Job satisfaction is one of the factors that affect organizational commitment and also has a role in the formation of affective commitment in which individual employees who have a strong affective commitment remain in the organization with a strong commitment to remain sustainable. Many factors influence satisfaction and commitment to mining companies, resulting in employees who have affective commitment where the level of loyalty of an employee is very high to the company.

Based on the problems that occur internally in mining companies regarding organizational culture, the transformational leadership style is one of the supporting factors for job satisfaction that will result in effective commitment based information technology. This study aims to determine how much influence organizational culture, transformational leadership style have on job satisfaction and employee affective commitment at mining companies based information technology. The results of this research can be used as a basis for development, added value to knowledge and progress, as well as information and advice for companies regarding the influence of organizational culture, transformational leadership styles on job satisfaction, resulting in affective commitment based information technology. 


\section{Literature review}

Organizational culture varies from organization to organization, in an organizational culture is a value that is influenced by cultural factors (LaGuardia, 2008). (Lewis, 2018) argues that organizational culture is a system of shared meaning held by organizational members that distinguish the organization from other organizations. According to (Harwiki, 2016), organizational culture is shared beliefs and values that give meaning to members of an institution and make these beliefs and values as rules/guidelines for behavior within the organization.

Holy Opinion (Lund, 2003) the influence of organizational culture on job satisfaction that organizational culture does not affect the increase in employee job satisfaction. The effect of transformational leaders on the job satisfaction of transformational leaders will increase employee job satisfaction.

Opinion (Schein, 2017) leadership is a social influence process where people can ask for help from others in achieving goals, several activities are included in leadership roles, and anticipate any activities related to organizational functions and maintenance of internal and external adaptation and leadership theory is a leader. formal organization.

The opinion of (Weiss \& Merlo, 2015) states that job satisfaction is a pleasant emotional state that results from appraising one's job in achieving or facilitating one's work and the definition of job satisfaction theory is that there are two theoretical factors that employees have two main types of needs, namely: 1 ) Cleanliness, namely the hygiene factor is a need that may be very satisfied with certain conditions called hygiene factors such as supervision, interpersonal relationships, working conditions, salary, benefits; 2) Motivation.

The opinion of (Mung et al., 2011) is that there is a significant positive relationship between transformational leadership style and job satisfaction with organizational commitment, the higher transformational leadership and job satisfaction, the higher the commitment to the organization. Organizational commitment is positively and significantly related to transformational leadership and job satisfaction even though the strength of the relationship is only low. The structure of the strength of the relationship starts with job satisfaction followed by transformational leadership styles. The results of the study indicate that organizational commitment is positively and significantly related to two independent variables, namely transformational leadership style and job satisfaction.

Information technology (IT) is the use of computers to store, retrieve, transmit, and manipulate data or information. IT is typically used within the context of business operations as opposed to personal or entertainment technologies.[2] IT is considered to be a subset of information and communications. Human Resource Management (HRM) includes activities such as recruiting, training, developing and rewarding people in the organization. HRM must aim at achieving competitiveness in the field of HR by providing constant educational and training programs for the personal and professional development of the employees of the organization.

It has been conventionally proved that Information and Communication Technology (ICT), such as the Internet, mobile communication, new media, and such in HR can greatly contribute to the fulfillment of personnel policies of the organization. Technological advancement can have a huge impact on the HR department of an organization. It allows the company to improve its internal processes, core competencies, relevant markets and organizational structure as a whole. Human Resource must mainly be focused on the strategic objectives of the organization. These strategies must be led to incorporate an IT strategic plan for the organization. These are activities related to any development in the technological systems of the entity, such as product design (research and development) and IT systems. Technology development is an important activity for the innovation process within the business, and may include acquired knowledge. In the context, all activities may have some technical content, and results in greater technological advancement. Information Technology may have a greater impact on organizations that exist in a dynamic environment. This will lead to greater efficiency and effectiveness of the Human Resources. Hence, utilizing IT application for database management and advances recruitment system will increase the efficiency of the business.

\section{Research methods}

This study uses a quantitative research method of data analysis using Purposive Sampling namely by using a non-probability sampling design, primary data, where data is collected using a questionnaire technique, validity test, reliability test, in this study using the SPSS version 17.0 program. The purpose of this method is to analyze the structure and measure variables so that the results can be used to test hypotheses. To determine whether there is an influence between organizational culture variables (X1), transformational leadership style (X2), on job satisfaction (Y1) results in affective commitment (Y2), in SPSS data processing, the population used is 111 samples, all respondents are employees of mining companies (Marvasti, 2018). 


\section{Results and Discussion}

The population used is 111 samples, all respondents are employees of mining companies. Of the 180 questionnaires distributed, only 140 were returned. Of the 111 valid questionnaires, all of them can be further analyzed. So that the response of employees to take the time to fill out the research questionnaire is $88.8 \%$. The following are the results of the characteristics of the respondents.

Table 1

\section{Demographic Characteristics of Respondents}

\begin{tabular}{lcc}
\hline $\begin{array}{l}\text { No. Characteristics } \\
\text { Demographics }\end{array}$ & $\begin{array}{c}\text { amount } \\
\text { (person) }\end{array}$ & $\begin{array}{l}\text { Percentage } \\
(\%)\end{array}$ \\
\hline 1. Gender & & \\
Men & 93 & $83.8 \%$ \\
Woman & 18 & $16.2 \%$ \\
& & \\
2. Age & 2 & $1.8 \%$ \\
$\leq 25$ years & 28 & $25.2 \%$ \\
26-35 years & 41 & $36.9 \%$ \\
36- 45 years & 40 & $36 \%$ \\
$>$ 45 years & & \\
& & \\
3. Education & 23 & $20.7 \%$ \\
Completed D3 & 80 & $72.1 \%$ \\
Graduated Bachelor & 8 & $7.2 \%$ \\
Graduated Postgraduate & & \\
& & \\
4. Years of service & 27 & $24.3 \%$ \\
$\leq$ 5 years & & $9 \%$ \\
6-10 years & & \\
$>$ 10 years & & \\
& & \\
\hline
\end{tabular}

Source: The results of data processing with SPSS version 17.0

From the data on the characteristics of respondents, the number of respondents who became the sample was more men than women with a ratio of 93 men $(83.8 \%)$ and 18 women $(16.2 \%)$. Based on the age of the respondents who were grouped into 4 (four) age groups, the most respondents were aged 36 to 45 as many as 41 people (36.9\%), employees who were more than 45 years old were 40 people (36\%), employees aged 2628 people $(25.2 \%)$ years to 35 years old, 2 employees less than 25 years old $(1.8 \%)$.

In terms of education, most of the first employee respondents came from undergraduate education as many as 80 people $(72.1 \%)$, employees who graduated from D3 education were 23 people $(20.7 \%)$, employees who graduated from postgraduate education were 8 people $(7.2 \%)$. The working period of the respondents stated that most of the first employees were working for more than ten years as many as 83 people (74.8\%), employees with a service period of fewer than five years were 27 people $(24.3 \%)$, employees with a working period of six to ten years were 1 people $(9 \%)$.

This study uses primary data, where data is collected using a questionnaire technique, which is to provide a written statement to the respondents, then the respondent responds to the statements given. This questionnaire is closed where the answers are readily available.

The validity test used in this study is the KMO and Bartlett's test of Sphericity with the help of SPSS version 17.0 software. The basis for decision-making is to look at the Kaiser-Meyer-Olkin Measure of Sampling Adequacy. The basis of decision making for the validity test is as follows (Statistics How To, 2016): if the value of KMO MSA $>0.5$ (valid) and if KMO MSA $<0.5$ (invalid). 
Table 2

Validity Test Results

\begin{tabular}{lcccc}
\hline Construct & Statement Items & Sig & KMO & Information \\
\hline $\begin{array}{l}\text { Organizational } \\
\text { culture }\end{array}$ & 6 & 0.000 & 0.710 & Valid \\
$\begin{array}{l}\text { Transformational } \\
\begin{array}{l}\text { Leadership Style } \\
\text { Job satisfaction }\end{array}\end{array}$ & 6 & 0.000 & 0.783 & Valid \\
$\begin{array}{l}\text { Affective } \\
\text { Commitment }\end{array}$ & 6 & 0.000 & 0868 & Valid \\
\hline
\end{tabular}

Source: The results of data processing with SPSS version 17.0

The results of validity testing for organizational culture variables contained six statement items, namely, the result is a KMO of 0.710 and a sig value. amounting to 0,000. This means that each statement item is declared valid because the KMO is more than 0.50 and the value is sig. less than 0.005 so that the statement items can represent or form a variable of organizational culture.

The results of the validity test for the transformational leadership style variable contained six statement items, namely, the result was a KMO of 0.783 and a sig value. amounting to 0,000 . This means that each statement item is declared valid because the KMO is more than 0.50 and the value is sig. less than 0.005 so that the statement items can represent or form the variables of transformational leadership style.

The results of the validity test for the job satisfaction variable contained six statement items, namely, the result is $\mathrm{KMO}$ of 0.868 and the sig value. amounting to 0,000 . This means that each statement item is declared valid because the KMO is more than 0.50 and the value is sig. less than 0.005 so that the statement items can represent or form a variable of job satisfaction.

The results of the validity test for the affective commitment variable contained six statement items, namely, the result is a KMO of 0.720 and a sig value. amounting to 0,000 . This means that each statement item is declared valid because the KMO is more than 0.50 and the value is sig. less than 0.005 so that the statement items can represent or form a variable of affective commitment.

The reliability test was carried out to determine the extent to which the measurement gave consistent results. Estimates in this study will use Cronbach's Alpha which shows how high the questionnaire items are correlated and related. The reliability test of each construct used in this study used the Cronbach's Alpha method with the help of SPSS version 17.0 software. According to (Christmann \& Van Aelst, 2006), Cronbach's alpha coefficient that is quite acceptable (acceptable) has a value between 0.60 to 0.70 or more. The results of reliability testing for each construct are shown for each construct shown in table 4 as follows:

Table 3

Reliability Test Results

\begin{tabular}{lll}
\hline Variable & Item & Cronbach's Alpha decision \\
\hline Organizational culture & 6 & 0.731 reliable \\
Transformational Leadership Style & 6 & 0.769 reliable \\
Job satisfaction & 6 & 0.900 reliable \\
Affective Commitment & 3 & 0.885 reliable
\end{tabular}

Source: The results of data processing with SPSS version 17.0

Based on the results of Cronbach's Alpha, all the variables studied were 0.60 to 0.70 or more so that all items in the measurement instrument could be declared reliable where the statement items used were appropriate to measure the variables under study. Based on the results of Cronbach's Alpha, all the variables studied were 0.60 to 0.70 or more, organizational culture was declared reliable at 0.731 , leadership style was declared reliable at 0.769 , job satisfaction was declared reliable at 0.900 , an affective commitment was declared reliable at 0.885 . 
Thus, all items in the measurement instrument can be declared reliable, where the statement items used, are appropriate to measure the variables under study.

Regarding the variables studied, it is known that there are four research variables (organizational culture, transformational leadership style, job satisfaction, affective commitment) which can be seen in Table 5 as follows:

Table 4

Descriptive statistics

\begin{tabular}{lccccc}
\hline \multicolumn{1}{c}{ Variable } & $\mathbf{n}$ & Minimum & Maximum & Mean & $\begin{array}{c}\text { Std } \\
\text { Deviation }\end{array}$ \\
\hline $\begin{array}{l}\text { Organizational } \\
\text { culture }\end{array}$ & 111 & 2.33 & 5.00 & 3.8018 & .62463 \\
$\begin{array}{l}\text { Transformational } \\
\text { Leadership Style }\end{array}$ & 111 & 1.00 & 4.83 & 3.7553 & .59537 \\
& & & & & \\
$\begin{array}{l}\text { Job satisfaction } \\
\begin{array}{l}\text { Affective } \\
\text { Commitment }\end{array}\end{array}$ & 111 & 1.00 & 5.00 & 3,6006 & .76717 \\
\hline
\end{tabular}

Source: The results of data processing with SPSS version 17.0

Based on table 4 (four), organizational culture obtained a variable average value (mean) of 3.8018 (min: 2.33, $\max 5.00$, and std. Deviation: 0.62463). This shows that the majority of respondents indicated that they almost agreed with the organizational culture with a value (mean) of 3.8018. From these studies, it was found that the existing organizational culture has not been applied consistently in the organization. There may be other factors such as promotion based on work performance that has not been generalized, job appraisal based on competence is still not entrenched.

Based on table 4 (four), the transformational leadership style obtained a variable mean value (mean) of 3.7553 ( $\min 1.00, \max 4.83$, and std. Deviation: 0.59537 ). This shows that the majority of respondents indicated that they almost agree with the transformational leadership style with the value (mean) 3.7553 . From these studies it was found that employees in these organizations do not agree with the transformational leadership style, there may be other factors that influence employees to want leaders who pay attention to employee needs, employees want democratic leaders more, can listen to input from their subordinates, involving employees, delegating authority, and encouraging participation, employees do not only appreciate work only on tasks and results.

Based on table 4 (four), job satisfaction obtained a variable average value (mean) of 3,6006 (min 1.00, max 5.00, and std. Deviation: 0.76717). This shows that the majority of respondents indicate that they almost agree with job satisfaction with the value (mean) 3,6006. These studies found there may be other factors that affect job satisfaction, such as 1) Increased competence; 2) Improved work performance; 3) Giving feedback; 3) Salary; 5) Promotion based on work performance.

Based on table 4 (four), affective commitment obtained a variable average value (mean) of 4.2042 (min 2.00, max 5.00, and std. Deviation: 0.72638). This shows that the majority of respondents indicated that they agreed with the commitment with a value (mean) of 4.2042. Affective commitment is good if the employee is emotionally committed, the employee survives, and is involved in the organization (Lok \& Crawford, 2004). This means that the needs and rights of employees are met which makes an employee feel proud of the organization they work for, feel ownership, love their job and are loyal to the organization, have a desire to be able to carry out their work to the maximum, which makes the desire to remain a member of the organization and loyalty against the organization. Testing of the two proposed hypotheses,

Table 5

Regression Calculation Results

\begin{tabular}{|c|c|c|c|c|c|c|c|}
\hline Variable & & $\beta$ & $\mathrm{t}$ & Sig & $\mathrm{R}$ & R Square & Result \\
\hline Job Satisfaction & $\longrightarrow$ & 0.457 & 5,368 & 0.000 & 0.457 & 0.209 & H1 received \\
\hline \multicolumn{8}{|c|}{ Organizational Culture } \\
\hline Leadership Style & $\longrightarrow$ & 0.363 & 4,067 & 0.000 & 0.363 & 0.132 & H1 accepted \\
\hline \multicolumn{8}{|l|}{ Transformational } \\
\hline \multicolumn{8}{|l|}{ Job satisfaction } \\
\hline Job satisfaction & $\longrightarrow$ & 0.448 & 5,227 & 0.000 & 0.448 & 0.200 & H1 accepted \\
\hline
\end{tabular}




Source: The results of data processing with SPSS version 17.0

Testing this hypothesis shows that there is an influence between organizational culture on job satisfaction. Testing the hypothesis proves that organizational culture has a positive influence on job satisfaction with a sig value of $0.000<0.05$ and a $\beta$ value of 0.457 . That the results of this study are not supported by research conducted by (Prasetyaningtyas, W. S., Raharjo, K., \& Afrianty, 2020) where the results of the hypothesis testing show that there is no significant influence of organizational culture (X2) on job satisfaction (Y2). This is indicated by a path coefficient value of 0.230 , the t-value is 1.667 , and the p-value is $0.098(\mathrm{p}>0.05)$. These results imply that $\mathrm{H} 4$ is not supported. In other words, organizational culture does not affect the increase in employee job satisfaction. and increased knowledge sharing activities.

Testing the transformational leader style hypothesis shows that there is a positive influence between the style of transformational leaders on job satisfaction. Testing the hypothesis proves that the style of the organization's transformational leader has a positive influence on job satisfaction with a sig value of $0.000<0.05$ and a $\beta$ value of 0.363 . That the results of this hypothesis are supported by research conducted by (Prasetyaningtyas, W. S., Raharjo, K., \& Afrianty, 2020). The results of hypothesis testing show that the transformational leadership variable (X1) has a positive and significant effect on job satisfaction (Y2). This can be proven by the path coefficient value of 0.315 , the t-count value of 2.710 , and the p-value of $0.008(\mathrm{p}<0.05)$. These results empirically support $\mathrm{H} 3$. Based on these results it can be concluded that transformational leadership will increase employee job satisfaction. And in line with Research using Pearson correlation analysis which shows that there is a significant positive relationship between transformational leadership style and job satisfaction with organizational commitment, $(\mathrm{r}=$ $.110, \mathrm{p}<.01$ and $\mathrm{r}=.359, \mathrm{p}<0.01$ ). This shows that the higher transformational leadership and job satisfaction, the higher the commitment to the organization.

This job satisfaction hypothesis testing shows that there is a positive influence between Joab satisfaction on affective commitment with a sig value of $0.000<0.05$ and a value of $\beta$ of 0.448 . That the results of this hypothesis are supported by research conducted In the regression analysis decision in the study $(\mathrm{N}=474)$, it was found that only one supporting factor emerged as a factor that contributed to organizational commitment. This factor is job satisfaction. This suggests that two factors contribute to organizational commitment. Significantly, the job satisfaction score $[\mathrm{F}(1.472)=70.04, \mathrm{p}<0.001]$ contributed as much as $12.9 \%$ variance $(\mathrm{R} 2.129)$ in the organizational commitment score. This means that job satisfaction $(\beta=.359, \mathrm{p}<.001)$ is a major indicator of organizational commitment, The results of the study show the relationship between organizational commitment is related positively and significantly with only two independent variables, namely transformational leadership style, and job satisfaction.

Human Resource Management (HRM) includes activities such as recruiting, training, developing and rewarding people in the organization. HRM must aim at achieving competitiveness in the field of HR by providing constant educational and training programs for the personal and professional development of the employees of the organization.

It has been conventionally proved that Information and Communication Technology (ICT), such as the Internet, mobile communication, new media, and such in HR can greatly contribute to the fulfillment of personnel policies of the organization. Technological advancement can have a huge impact on the HR department of an organization. It allows the company to improve its internal processes, core competencies, relevant markets and organizational structure as a whole. Human Resource must mainly be focused on the strategic objectives of the organization. These strategies must be led to incorporate an IT strategic plan for the organization. These are activities related to any development in the technological systems of the entity, such as product design (research and development) and IT systems. Technology development is an important activity for the innovation process within the business, and may include acquired knowledge. In the context, all activities may have some technical content, and results in greater technological advancement. Information Technology may have a greater impact on organizations that exist in a dynamic environment. This will lead to greater efficiency and effectiveness of the Human Resources. Hence, utilizing IT application for database management and advances recruitment system will increase the efficiency of the business. 


\section{Conclusion}

From these studies, it can be concluded that the results of this study ba good organizational culture are very important to increase job satisfaction. Good job satisfaction will improve employee performance to be more productive so that the company is more efficient based Information technology.

Transformational leadership style (transformational leadership style): a stimulating leader inspires his subordinates to achieve extraordinary results. Transformational leadership style is very influential in creating good job satisfaction. High job satisfaction affects employee performance so that it benefits the organization.

Job satisfaction affects affective commitment, job satisfaction is a pleasant emotional state that results from appraising one's job to achieve or facilitate one's work values, the theory of job satisfaction, job satisfaction in addition to improving employee performance also affects employee affective commitment to create: 1) job loyalty; 2) Competence improvement; 3) Improved work performance.

The advantages for organizations with affective commitment include: 1) Employee turnover can be suppressed well, it can be seen that employees have survived more than five years. 2) Recruitment costs can be managed or minimized; 3) The organization can concentrate more on business development and increasing organizational profits based Information technology.

\section{Reference}

1. Christmann, A., \& Van Aelst, S. (2006). Robust estimation of Cronbach's alpha. Journal of Multivariate Analysis. https://doi.org/10.1016/j.jmva.2005.05.012

2. Harwiki, W. (2016). The Impact of Servant Leadership on Organization Culture, Organizational Commitment, Organizational Citizenship Behaviour (OCB) and Employee Performance in Women Cooperatives. Procedia - Social and Behavioral Sciences. https://doi.org/10.1016/j.sbspro.2016.04.032

3. LaGuardia, D. (2008). Organizational culture. T and D. https://doi.org/10.5848/amacom.978-0-81441753-9 20

4. Lewis, D. (2018). Culture and Organization. In Non-Governmental Organizations, Management and Development. https://doi.org/10.4324/9780203591185-8

5. Lok, P., \& Crawford, J. (2004). The effect of organisational culture and leadership style on job satisfaction and organisational commitment: A cross-national comparison. Journal of Management Development. https://doi.org/10.1108/02621710410529785

6. Lund, D. B. (2003). Organizational culture and job satisfaction. Journal of Business and Industrial Marketing. https://doi.org/10.1108/0885862031047313

7. Marvasti, A. (2018). Research methods. In The Cambridge Handbook of Social Problems. https://doi.org/10.1017/9781108656184.003

8. Mung, L. V., May-Chiun, L., Kwang Sing, N., \& Ayob, N. (2011). The Influence of Leadership Styles on Employees 'Job Satisfaction in Public Sector Organizations in Malaysia. International Journal of Business, Management and Social Sciences.

9. Prasetyaningtyas, W. S., Raharjo, K., \& Afrianty, T. W. (2020). Pengaruh kepemimpinan transformasional dan budaya organisasi terhadap knowledge sharing dan kepuasan kerja. Jurnal Ekonomi Dan Bisnis, 23(2), 379-399.

10. Schein, E. (2017). Organizational Culture and Leadership Organizational Culture and Leadership. Wiley \& Sons, Inc.

11. Statistics How To. (2016). Kaiser-Meyer-Olkin (KMO) Test for Sampling Adequacy. In Stephanie.

12. Weiss, H. M., \& Merlo, K. L. (2015). Job Satisfaction. In International Encyclopedia of the Social \& Behavioral Sciences: Second Edition. https://doi.org/10.1016/B978-0-08-097086-8.22029-1 